Brit. J. vener. Dis. (1958), 34, 124.

\title{
BRITISH FEDERATION AGAINST THE VENEREAL DISEASES
}

BY

\author{
C. S. NICOL
}

The progress of the British Federation against the Venereal Diseases was last reviewed 4 years ago, when details were given of achievements up to the end of 1953, and the programme for 1954 was forecast (Nicol, 1954a).

It is now possible to list the Federation's activities up to the end of 1957; this is best done by summarizing the Joint Secretaries' reports for the years 1954, 1955,1956 , and 1957.

\section{4}

(1) A memorandum on non-gonococcal urethritis was submitted to the Executive Committee.

(2) A meeting of the Society of Medical Officers of Health was held and two papers were read on the subject of non-gonococcal urethritis; these were followed by a discussion (Harkness, 1954; Nicol, 1954b).

(3) The editor of the British Medical Journal agreed to publish the quarierly Ministry of Health Statistics of Venereal Diseases in the Epidemiology Section as a result of an approach by the B.F.V.D.

(4) Following an unofficial approach, a discussion took place with a B.B.C. representative about a radio programme on the subject of venereal disease, but this did not result in any action.

(5) There were further discussions on a film-strip on venereal diseases for group leaders to use in group discussions. A number of Youth Organizations approached were, however, not interested in this project.

(6) Support was given to the new United Kingdom Committee of W.H.O. to which a donation was made.

(7) The pamphlet "Do You Know ?", published by the Central Council for Health Education, was revised.
1955

(1) A study of the social aspects of gonorrhoea was undertaken in association with the British Cooperative Clinical Group. A preliminary paper was presented at the meeting of the Union Internationale contre le Péril Vénérien at Naples and further papers were published later, (British Cooperative Clinical Group, 1956; Nicol, 1956).

(2) To gather information for the Central Council for Health Education about sex education and anti-V.D. propaganda, a questionnaire was approved and completed from details given by patients attending a London V.D. Clinic.

\section{6}

(1) A preliminary report on 180 completed questionnaires from the London V.D. Clinic mentioned above proved of interest; the survey therefore was extended to another V.D. Clinic in London and to a V.D. Clinic in the North of England.

(2) By arrangement with the British Social Biology Council, the film "The Invader" was shown to an invited audience of workers in the field of social medicine, and the views of these representatives were recorded.

(3) There was no meeting of the U.I.P.V., but at the request of the President, Dr. Hermans, the names of Indian doctors who might help in the opening of an U.I.P.V. Regional Office in New Delhi were supplied.

(4) Representatives of the Executive Committee attended the Meeting on "Prostitution" held by the Association for Moral and Social Hygiene.

(5) The Ministry of Health, Jamaica, joined the Federation.

(6) In view of the unsatisfactory financial position of the Federation, various Drug Firms were 
asked to give support. Messrs. May and Baker and Messrs. Boots Pure Drug Co. both very generously promised to give the B.F.V.D. $£ 10$ 10s. Od. annually for seven years, and Messrs. Smith, Kline, and French gave a donation of $£ 3$. $3 \dot{s}$. $0 d$.

\section{7}

(1) The questionnaires from the V.D. Clinics mentioned above were completed and submitted via the Central Council for Health Education for publication.

(2) An analysis of the contacts of male patients attending four clinics in London was presented at the U.I.P.V. Meeting at Stockholm by the B.F.V.D. At the same Meeting a paper on "Prostitution" was read by Mr. A. J. King, and a paper on "The value of the voluntary principle in the control of V.D." by Miss Chave Collisson (U.I.P.V., 1957).

(3) After lengthy preliminary deliberations, a group discussion project is to be organized by Dr. Dalzell-Ward of the Central Council for Health Education. Patients from a London V.D. Clinic will be asked to volunteer to attend group discussions, which will deal in general terms with the problems of venereal diseases and will be recorded meetings.

The following Officers and Executive Committee of the B.F.V.D. were elected for 1957-1958:

Chairman: Dr. J. A. Scott.

Association for Moral and Social Hygiene: Miss M. Chave Collisson.
Apostleship of the Sea: Mr. A. J. King.

British Medical Association: Dr. F. J. G. Jefferiss.

British Social Biology Council: Mrs. C. R. Gruby (Hon. Secretary).

Central Council for Health Education: Dr. A. J. DalzellWard.

Church of England Moral Welfare Council: Rev. G. R. Dunstan.

Institute of Almoners: Miss M. C. Haworth.

Invalid Children's Aid Association: Dr. L. Fairfield.

Medical Society for the study of Venereal Diseases: Col. L. W. Harrison, (Hon. Treasurer); Dr. C. S. Nicol, (Hon. Secretary).

Missions to Seamen: Rev. J. E. C. Lawlor.

National Association for Maternal and Child Welfare: Miss I. V. Evelyn.

National Association of Probation Officers: Miss M. C. Paterson.

National Council of Women: Mrs. M. F. Bligh. (Vice Chairman).

Royal College of Nursing: Miss B. Tarratt.

Scottish Council for Health Education: Mr. W. A. Morrison.

Co-opted Members: Dr. Mary Michael-Shaw, Dr. G. L. M. McElligott, Mrs. E. M. Bowyer.

Hon. Solicitor: Mr. E. K. Kelsey

Hon. Accountants: Singleton and Fabian and Co.

\section{REFERENCES}

British Cooperative Clinical Group Gonorrhoea Study (1956). Brit. J. vener. Cis., 32, 21.

British Federation against the Venereal Diseases (1958). Med. Offr, 99, 163.

Harkness, A. H. (1954). Publ. Hlth, 68, 10.

Nicol, C. S. (1954a). Brit. J. vener. Dis., 30, 170

- (1954b). Publ. Hlth, 68, 10

- (1956). Brit. J. vener. Dis. $32,27$.

Union Internationale contre le Péril Vénérien (1957) Ibid., 33, 128. 